\title{
Impact of the Preoperative Neutrophil to Lymphocyte Ratio on Patients with Head and Neck Cancer
}

\author{
Geun-Jeon Kim, Jun-Myung Kang, Jae-Hyun Seo, Se-Hwan Hwang, Ho-Young Youn, \\ Ho-Jun Jin, Ha-Ram Kang, Hyun-Ho Lee, and Young-Hoon Joo ${ }^{D}$ \\ Department of Otolaryngology-Head and Neck Surgery, College of Medicine, The Catholic University of Korea, Seoul, Korea
}

\author{
두경부 암 환자에서 수술 전 호중구-림프구 비율의 임상적 효용성 \\ 김근전 · 강준명 · 서재현 · 황세환 · 윤호영 · 진호준 · 강하람 - 이현호 · 주영훈 \\ 가톨릭대학교 의과대학 이비인후과학교실
}

\author{
Received August 21, 2018 \\ Revised May 6, 2019 \\ Accepted May 27, 2019 \\ Address for correspondence \\ Young-Hoon Joo, MD, PhD \\ Department of Otolaryngology- \\ Head and Neck Surgery, \\ College of Medicine, \\ The Catholic University of Korea, \\ 327 Sosa-ro, Bucheon 14647, Korea \\ Tel $+82-32-304-7090$ \\ Fax $+82-32-340-2674$ \\ E-mail joodoct@catholic.ac.kr
}

Background and Objectives To investigate the prognostic value of the neutrophil to lymphocyte ratio (NLR) in patients with head and neck squamous cell cancer (HNSCC).

Subjects and Method Clinical data from 259 patients with HNSCC were collected retrospectively. NLR was adopted as potential prognostic biomarkers.

Results NLR was associated with cancer recurrence ( $p=0.002$ and $p<0.001$, respectively). Patients with a NLR $>2.15$ had significantly decreased 5-year disease specific survival (DSS) based on the Kaplan-Meier survival curves ( $p<0.001$ and $p=0.029$, respectively). The Multivariate Cox regression analysis confirmed a significant association between 5-year DSS and the NLR (using 2.15 as the cut-off; hazard ratio, 1.852; 95\% confidence interval, 1.237-2.771; $p=$ $0.003)$.

Conclusion A NLR cut-off value $\geq 2.15$ was associated with adverse outcomes in patients with HNSCC. Korean J Otorhinolaryngol-Head Neck Surg 2020;63(1):26-30

Key Words Head and neck neoplasms · Hematologic tests · Prognosis · Recurrence · Squamous cell carcinoma.

\section{서 론}

두경부에 발생하는 편평상피암은 미국에서 연간 4만 명에 달한다. ${ }^{1)}$ 한국에서는 연간 3400예의 두경부 암 발생을 보이 며 이는 전체 암의 $2.6 \%$ 에 해당한다. ${ }^{2}$ 두경부 암에서 진단과 치료법은 상당한 발전을 했음에도 불구하고 5년 생존율은 여 전히 $50 \%$ 미만이며 적절한 치료 후에도 재발을 잘하므로 따 라서 예후에 대한 예측 및 평가, 적절한 술 후 치료의 선택을 위해서는 신뢰할 수 있고 단순한 예측인자가 필요하다. ${ }^{3,4}$

암 환자에서 예후인자로서 혈액 수치(hematological parameter)에 대한 관심이 증가하고 있다. ${ }^{5-9)}$ 중성구, 림프구 및

This is an Open Access article distributed under the terms of the Creative Commons Attribution Non-Commercial License (https://creativecommons.org/licenses/by-nc/4.0) which permits unrestricted non-commercial use, distribution, and reproduction in any medium, provided the original work is properly cited.
혈소판의 수는 단독 또는 그 발현 비율이 예후와 관련되어 있다. 두경부암에서도 치료 결과를 예측하기 위해 저가이면 서 객관적이고 쉽게 검출되는 표지자를 선별하는 것이 매우 중요하다. 호중구-림프구 비율(neutrophil to lymphocyte ratio)은 전신 염증 상태를 반영하는 표지로 백혈구 수치를 통 해 쉽게 계산되며 다양한 종류의 암을 가진 환자들에서 독 립적인 예후인자로 보고되고 있다. ${ }^{10)}$

이에 본 연구에서는 두경부 편평상피암으로 진단받은 후 두경부재건술을 시행한 환자에서 호중구-림프구 비율이 재 발과 생존을 예측할 수 있는 예후인자로서 의미가 있는지 알 아보고자 하였다. 
Preoperative Neutrophil to Lymphocyte Ratio I Kim GJ, et al.

\section{대상 및 방법}

본원 이비인후과에서 2006년 3월부터 2017년 12월까지 두 경부에 발생한 편평상피암에서 원발부위 광범위 절제술 및 두경부재건술을 받은 환자를 대상으로 후향적 의무기록 조 사를 시행하였다. 모든 환자들은 영상학적으로 원격 전이는 없었고 완치 목적으로 치료를 받았으며 연령, 성별, 병리학적 진단(TNM 단계 포함), 종양 위치, 진단 날짜, 재발 날짜, 사망 날짜 등의 특징을 의무기록을 통해 정리하였다.

모든 대상 환자에게서 수술 전 4주 이내 채혈 검사를 시행 하였다. 어떤 환자에서도 패혈증, 혈액 질환의 임상적 징후는 보이지 않았고 혈액 검사 당시 면역억제제를 복용하고 있지 않았다. 검사 항목으로는 총 백혈구 수치(total white blood cell count) 및 백혈구 중 세부적으로 호중구, 림프구의 수치 를 측정하였으며 혈소판(platelet), 헤모글로빈(hemoglobin), 알부민(albumin), 크레아티닌(creatinine)을 측정하였다. 호중 구-림프구 비율은 호중구 수를 림프구 수로 나눈 값이다. 병기 는 2002년 미국 암 학회(American Joint Committee on Cancer) TNM 체계에 따라 분류하였으며, 후향적 의무기록의 조 사와 보관된 종양 표본의 사용에 대해 본원의 임상연구심의 위원회(IRB)의 승인을 받은 후 진행하였다(HC17SIS10006).

\section{통계 분석}

통계는 SPSS statistics version 16.0(SPSS Inc., Chicago, IL, USA)을 이용하여 chi-square test, Fisher's exact test를 시행하여 상관 관계를 분석하였다. 재발과 연관된 가장 적절 한 절단값(cut-off value)의 호중구-림프구 비율을 도출하기 위해 receiver operating characteristics(ROC) curve를 시 행하였고, 무병 생존율(disease-specific survival rate, DSS) 은 Kaplan-Meier method를 이용하였다. Cox 비례위험모형 (proportional hazards model)과 우도비 검정(likelihood ratio statistics)을 이용하여 생존율과 관련된 중요하고 독립적 인 변수를 확인했다. $p$-value가 0.05 미만인 경우에 통계적 으로 유의한 것으로 판단하였으며 숫자 데이터는 평균ㅍㅍㅛ 준 편차로 표현하였다.

\section{결 과}

\section{환자 및 종양 특성}

두경부 편평상피암으로 진단받은 259명이 포함되었고 남 자는 229명, 여자는 30명이었으며 평균 연령은 56.8세, 연령 분포는 20 세에서 78 세였다. 원발암의 부위에 따라 분류하면 구강암이 99예로 38.2\%를 차지하였으며, 구인두암이 83예
(32.1\%), 하인두암이 62예(23.9\%), 비강암이 13예(5.0\%), 후두 암이 2예(0.8\%)순이었다. 병리학적 T병기는 $\mathrm{T} 1$ 이 10예(3.8\%), $\mathrm{T} 2$ 가 123예(47.5\%), T3가 74예(28.6\%), T4가 52예(20.1\%)로

Table 1. Patient demographic characteristics $(n=259)$

\begin{tabular}{|c|c|}
\hline Parameter & Number of patients \\
\hline Age (years) & $56.8 \pm 10.5$ \\
\hline \multicolumn{2}{|l|}{ Gender (\%) } \\
\hline Male & $229(88.4)$ \\
\hline Female & $30(11.6)$ \\
\hline \multicolumn{2}{|l|}{ History of diabetes (\%) } \\
\hline Yes & $40(15.4)$ \\
\hline No & $219(84.6)$ \\
\hline \multicolumn{2}{|l|}{ History of hypertension (\%) } \\
\hline Yes & $42(16.2)$ \\
\hline No & $217(83.8)$ \\
\hline \multicolumn{2}{|l|}{ Primary site (\%) } \\
\hline Oral cavity & 99 (38.2) \\
\hline Oropharynx & $83(32.1)$ \\
\hline Hypopharynx & $62(23.9)$ \\
\hline Nasal cavity & $13(5.0)$ \\
\hline Larynx & $2(0.8)$ \\
\hline \multicolumn{2}{|l|}{ Flap type (\%) } \\
\hline Radial forearm & $199(76.8)$ \\
\hline Anterolateral thigh & $48(18.5)$ \\
\hline Rectus abdominis & $7(2.7)$ \\
\hline Fibular & $3(1.2)$ \\
\hline Lateral thigh & $2(0.8)$ \\
\hline \multicolumn{2}{|l|}{ T classification $(\%)$} \\
\hline $\mathrm{T} 1$ & $10(3.8)$ \\
\hline $\mathrm{T} 2$ & $123(47.5)$ \\
\hline Т3 & $74(28.6)$ \\
\hline $\mathrm{T} 4$ & $52(20.1)$ \\
\hline \multicolumn{2}{|l|}{ N classification (\%) } \\
\hline NO & $79(30.5)$ \\
\hline N1 & $58(22.4)$ \\
\hline N2 & $117(45.2)$ \\
\hline N3 & $5(1.9)$ \\
\hline \multicolumn{2}{|c|}{ Preoperative (chemo) radiotherapy (\%) } \\
\hline Yes & $33(12.7)$ \\
\hline No & $226(87.3)$ \\
\hline White blood cell count ( $\left.10^{9} / \mathrm{L}\right)$ & $6.95 \pm 2.35$ \\
\hline Neutrophil count $\left(10^{9} / \mathrm{L}\right)$ & $4.28 \pm 1.99$ \\
\hline Lymphocyte count (10\%/L) & $1.98 \pm 1.14$ \\
\hline Platelet count $\left(10^{9} / \mathrm{L}\right)$ & $250.4 \pm 93.7$ \\
\hline Neutrophil to lymphocyte ratio & $2.65 \pm 2.41$ \\
\hline Platelet to lymphocyte ratio & $150.4 \pm 89.8$ \\
\hline Hemoglobin (g/dL) & $13.6 \pm 1.55$ \\
\hline Albumin (g/dL) & $4.18 \pm 0.59$ \\
\hline Creatinine (mg/dL) & $0.91 \pm 0.18$ \\
\hline
\end{tabular}

Continuous variables are mean \pm standard deviation 
확인되었고 N병기는 N0부터 N3까지 79예(30.5\%), 58예 (22.4\%), 117예(45.2\%), 5예(1.9\%)였다. 수술 전 (화학)방사선 치료를 받은 환자 33명(12.7\%)을 제외한 226명(87.3\%)은 1차 치료로 수술을 시행한 환자였다(Table 1).

\section{수술 전 호중구-림프구 비율과 예후와의 연관성}

평균 추적 관찰 기간은 49.5개월(범위, 1 239개월)이었으 며 재발이나 전이는 99명(38.2\%)의 환자에서 발생하였다. 재 발과 호중구 수 $(p=0.015)$, 림프구 수 $(p=0.032)$, 수술 전 호중 구-림프구 비율 $(p=0.002)$ 사이에 통계적으로 유의한 상관 관 계가 관찰되었다. 재발한 환자의 평균 수술 전 호중구-림프 구 비율은 3.35 \pm 3.33 이었고 재발하지 않은 환자는 $2.21 \pm 1.45$ 였다(Table 2). 재발 유무를 구별하기 위한 수술 전 호중구림프구 비율의 ROC 분석은 ROC 곡선 아래 면적을 통해 비 교하였으며 67.3\%(63.9 70.7\%, $p<0.001$ )였다. 또한 ROC 분 석 결과 수술 전 수술 전 호중구-림프구 비율의 cut-off 값 은 각각 2.15 (민감도 $=65.7 \%$, 특이도=66.9\%)였다(Fig. 1). 백혈 구 $(p=0.177)$, 혈소판 $(p=0.068)$, 헤모글로빈 $(p=0.154)$, 알부민 $(p=0.134)$ 및 크레아티닌 $(p=0.679)$ 수치는 재발과 유의한 관 련성을 보이지 않았다(Table 2).

5년 질병특이생존율은 63\%로 수술 전 호중구-림프구 비 율(cut-off value=2.15, $p<0.001$ )과 유의한 상관 관계를 보였 다(Fig. 2), 고령( $p=0.007)$, 진행된 $\mathrm{pT}$ 병기 $(p=0.028), \mathrm{pN}$ 병기 $(p=0.005)$ 및 수술 전 (항암)방사선 요법의 시행 $(p<0.001)$ 은 5 년 질병특이생존율과 단변량분석에서 연관성을 보였다.

다변량 $\operatorname{Cox}$ 회귀분석결과 5년 질병특이생존율은 호중구림프구 비율[cut-off 수치, 2.15; 위험비(hazard ratio), 1.852; 95\% 신뢰구간(confidence interval), 1.237 2.771; $p=0.003]$, $\mathrm{pN}$ 병기(위험비, 1.975; 95\% 신뢰구간, 1.340 2.909; $p=0.001$ ), 수술 전 (항암)방사선 요법(위험비, 2.413; 95\% 신뢰구간 1.460 3.988; $p=0.001)$ 과 통계적으로 유의한 연관성이 있음을 확인 하였다(Table 3).

\section{고 찰}

이번 연구에서 원발부위 절제술 및 재건술을 받은 두경부

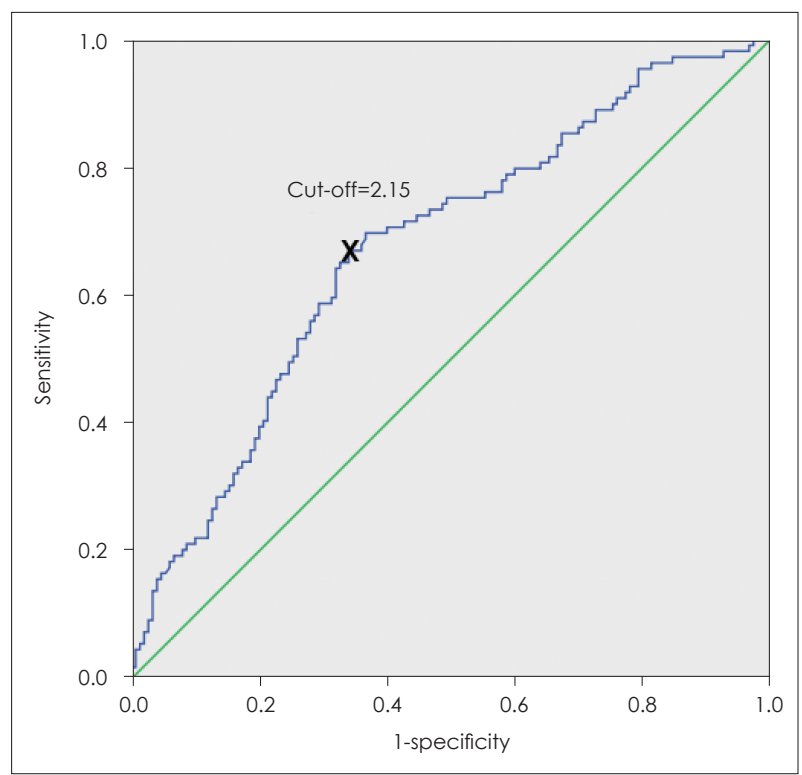

Fig. 1. Receiver operating characteristic curve for the neutrophil to lymphocyte ratio for recurrence (area under the curve was $0.674 \pm$ $0.034, p<0.001)$

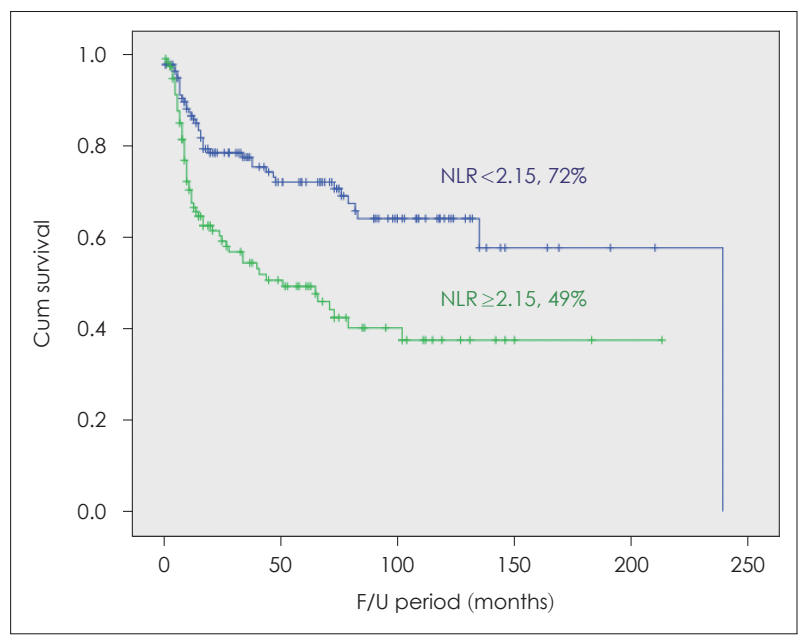

Fig. 2. Kaplan-Meier disease-specific survival curve according to the neutrophil to lymphocyte ratio. A significant association was detected between the neutrophil to lymphocyte ratio and 5-year disease-specific survival $(p<0.001)$. NLR: neutrophil to lymphocyte ratio.

Table 2. Distribution of hematological parameters based on postoperative complications and recurrence

\begin{tabular}{lcccccccc}
\hline $\begin{array}{c}\text { Postoperative } \\
\text { complication }\end{array}$ & $\begin{array}{c}\text { WBC } \\
\left(10^{9} / \mathrm{L}\right)\end{array}$ & $\begin{array}{c}\text { Neutrophil } \\
\left(10^{9} / \mathrm{L}\right)\end{array}$ & $\begin{array}{c}\text { Lymphocyte } \\
\left(10^{9} / \mathrm{L}\right)\end{array}$ & $\begin{array}{c}\text { Platelet } \\
\left(10^{9} / \mathrm{L}\right)\end{array}$ & NLR & $\begin{array}{c}\text { Hemoglobin } \\
(\mathrm{g} / \mathrm{dL})\end{array}$ & $\begin{array}{c}\text { Albumin } \\
(\mathrm{g} / \mathrm{dL})\end{array}$ & $\begin{array}{c}\text { Creatinine } \\
(\mathrm{mg} / \mathrm{dL})\end{array}$ \\
\hline Recurrence & & & & & & & & \\
Yes & $7.21 \pm 2.21$ & $4.65 \pm 1.86$ & $1.78 \pm 0.75$ & $265.4 \pm 118.6$ & $3.35 \pm 3.33$ & $13.40 \pm 1.40$ & $4.07 \pm 0.70$ & $0.91 \pm 0.20$ \\
No & $6.80 \pm 2.42$ & $4.04 \pm 2.03$ & $2.10 \pm 1.32$ & $241.1 \pm 73.1$ & $2.21 \pm 1.45$ & $13.68 \pm 1.63$ & $4.24 \pm 0.51$ & $0.90 \pm 0.17$ \\
p-value & 0.177 & $0.015^{*}$ & $0.032^{*}$ & 0.068 & $0.002^{*}$ & 0.154 & 0.134 & 0.679 \\
\hline
\end{tabular}

Continuous variables are mean \pm standard deviation. *statistically significant. WBC: white blood cell, NLR: neutrophil to lymphocyte ratio 
Preoperative Neutrophil to Lymphocyte Ratio I Kim GJ, et al.

Table 3. Cox proportional hazards analysis for 5-year survival

\begin{tabular}{lccc}
\hline \multicolumn{1}{c}{ Parameter } & Hazard ratio & $95 \%$ confidence interval & $p$-value \\
\hline Age $(\geq 60$ vs. $<59$ years) & 1.586 & $0.756-2.382$ & 0.326 \\
Pathologic T stage (T1/2 vs. T3/4) & 1.165 & $0.785-1.727$ & 0.448 \\
Pathologic N stage (N0/1 vs. N2/3) & 1.975 & $1.340-2.909$ & $0.001^{*}$ \\
Preoperative (chemo) radiotherapy & 2.413 & $1.460-3.988$ & $0.001^{*}$ \\
NLR (2.15 as a cut-off) & 1.852 & $1.237-2.771$ & $0.003^{*}$ \\
\hline
\end{tabular}

*statistically significant. NLR: neutrophil to lymphocyte ratio

암 환자에서 재발의 독립적인 예측인자 및 생존율의 예후 지 표로서 수술 전 호중구-림프구 비율의 임상적 유용성을 확인 하였다. 2.15 이상의 수술 전 호중구-림프구 비율은 단변량 및 다변량 분석을 통해 근치적 수술을 받는 환자의 생존율 저 하와 관련이 있었다.

여러 앞선 연구에서는 호중구-림프구 비율이 전신성 염증 및 면역 반응의 지표 역할을 하며 두경부 암을 비롯한 여러 암 에서 임상적 예후를 예측할 수 있다고 보고되었다. ${ }^{11-17)}$ 호중 구는 사이토카인을 생산하여 종양이 발달하는 여러 단계에 관여하는 염증 세포의 한 유형으로 상대적 호중구증가증은 혈관내피성장인자, 성장인자(CXCL8), 프로테아제(metalloproteinase의 억제제), 종양 성장을 유도하는 항-세포자멸 인 자 $(\mathrm{NF}-\mathrm{kB})$ 와 같은 전 혈관 신생인자를 비롯한 염증 표지자 의 수를 증가시킨다. ${ }^{11-14)}$ 반면에 림프구는 면역 감시를 담당 하며 암 세포를 제거하는데 여기서 하나의 가설은 종양 침윤 에 대한 세포 매개 반응이 림프구 의존성이라는 것이다. 따라 서 종양 변연(margin)에서의 낮은 림프구 침윤은 불량한 예 후와 관련된다. ${ }^{15-17)}$

본 연구 또한 두경부 암 환자에서 높은 호중구와 낮은 림프 구 수가 종양의 재발과 유의한 상관 관계가 있음을 보여주었 으며, 2.15 이상의 수술 전 호중구-림프구 비율을 통해 재발 을 예측할 수 있다는 점이다. 수술 전 호중구-림프구 비율값 이 2.15 이상인 118 명의 환자 중 55 명 $(55 \%)$ 이 재발을 보였으 나 수술 전 호중구-림프구 비율값이 2.15 미만인 141명 중 34 명(24\%)이 재발을 보였다. 두경부 편평상피세포암 환자에서 평균 호중구-림프구 비율값 2.15가 재발을 진단하는 도구로 서 유용하며, 민감도와 특이도는 각각 $65.7 \%$ 와 $66.9 \%$ 였다. Sun 등 ${ }^{18)}$ 의 연구에서 비인두암 환자에서 수술 전 호중구-림 프구 비율의 cut-off값으로 2.7이 무진행생존(progressionfree survival)과 유의한 관련이 있다고 보고했다. Song 등 ${ }^{19)}$ 은 근치적 수술을 시행한 하인두암 환자에서 높은 호중구-림프 구 비율 $(\geq 2.3)$ 이 수술 부위 합병증 및 생존율과 관련이 있다 고 밝혔다. Sarraf 등 ${ }^{20)}$ 은 3.81의 호중구-림프구 비율이 최대 값의 민감도와 특이도에 상응하고 이것이 수술적 절제술만 으로 치료받은 1 기 비소 세포 폐암 환자에서 생존율을 예측할
수 있다고 보고하였다. 호중구-림프구 비율의 최적 cut-off 값은 앞으로의 다양한 연구를 통해 종양부위와 환자군에 따 라 분류하여 결정되어야 할 것이다.

본 연구의 제한점은 후향적 연구 분석이라는 점, 연구에 포 함된 두경부 암 환자 수가 많지 않다는 점, 대상자 수가 다른 다양한 원발부위암이 포함된 점, 림프구-단핵구 비, $\mathrm{C}-$ 반응 단백질과 같은 일부 혈액학적 지표를 파악할 수 없었다는 것 이다. 또한, $\mathrm{ROC}$ 곡선에서 적절한 cut-off 수치를 정하기에 는 모집단의 크기가 작다는 한계가 있다. 또한 이 연구의 추적 관찰 기간이 다소 짧다는 점이며, 향후 연구에서는 대단위 환 자군에 대한 분석을 통해 더 나은 결과를 도출하고자 한다.

본 연구에서는 두경부 편평상피암으로 진단 후 두경부재건 술을 받은 환자에서 수술 전 호중구-림프구 비율이 재발과 생존을 예측할 수 있는 예후인자로서 사용할 수 있음을 확인 하였다. 두경부 암의 수술적 치료를 시행하는 환자들에게 예 후를 예측할 수 있는 추가적인 인자로 염두해두어야 하며 환 자 진료 시 참고하여야 할 것으로 사료된다.

\section{Author Contribution}

Conceptualization: Young-Hoon Joo. Data curation: Geun-Jeon Kim, Jun-Myung Kang. Formal analysis: Geun-Jeon Kim, Ha-Ram Kang. Investigation: Young-Hoon Joo, Geun-Jeon Kim. Methodology: Young-Hoon Joo, Geun-Jeon Kim, Ho-Jun Jin. Project administration: Young-Hoon Joo. Resources: Young-Hoon Joo. Supervision: Jae-Hyun Seo, Se-Hwan Hwang. Validation: Ho-Young Youn, Hyun-Ho Lee. Visualization: Geun-Jeon Kim. Writing - original draft: Geun-Jeon Kim. Writing — review \& editing: Young-Hoon Joo.

\section{ORCID}

Young-Hoon Joo https://orcid.org/0000-0002-1158-0974

\section{REFERENCES}

1) Jain S, Khuri FR, Shin DM. Prevention of head and neck cancer: Current status and future prospects. Curr Probl Cancer 2004;28(5): 265-86.

2) National Cancer Information Center. 2015 Annual report of the Korea Central Cancer Registry [serial online] 2018 Apr 24 [cited 2018 Aug 1]. Available from: URL: https://ncc.re.kr/cancerStatsView.ncc ?bbsnum $=438 \&$ searchKey $=$ total $\&$ searchValue $=\&$ pageNum $=1$.

3) Dasgupta S, Koch R, Westra WH, Califano JA, Ha PK, Sidransky $\mathrm{D}$, et al. Mitochondrial DNA mutation in normal margins and tumors of recurrent head and neck squamous cell carcinoma patients. 
Cancer Prev Res (Phila) 2010;3(9):1205-11

4) Lee JM, Turini M, Botteman MF, Stephens JM, Pashos CL. Economic burden of head and neck cancer. A literature review. Eur J Health Econ 2004;5(1):70-80.

5) Grivennikov SI, Greten FR, Karin M. Immunity, inflammation, and cancer. Cell 2010;140(6):883-99.

6) Pei D, Zhu F, Chen X, Qian J, He S, Qian Y, et al. Pre-adjuvant chemotherapy leukocyte count may predict the outcome for advanced gastric cancer after radical resection. Biomed Pharmacother 2014; 68(2):213-7.

7) Tsai YD, Wang CP, Chen CY, Lin LW, Hwang TZ, Lu LF, et al. Pretreatment circulating monocyte count associated with poor prognosis in patients with oral cavity cancer. Head Neck 2014; 36(7):947-53.

8) Ishizuka M, Nagata H, Takagi K, Iwasaki Y, Kubota K. Combination of platelet count and neutrophil to lymphocyte ratio is a useful predictor of postoperative survival in patients with colorectal cancer. $\mathrm{Br} \mathrm{J}$ Cancer 2013;109(2):401-7.

9) Rachidi S, Wallace K, Day TA, Alberg AJ, Li Z. Lower circulating platelet counts and antiplatelet therapy independently predict better outcomes in patients with head and neck squamous cell carcinoma. J Hematol Oncol 2014;7:65.

10) Templeton AJ, McNamara MG, Šeruga B, Vera-Badillo FE, Aneja $\mathrm{P}$, Ocaña A, et al. Prognostic role of neutrophil-to-lymphocyte ratio in solid tumors: A systematic review and meta-analysis. J Natl Cancer Inst 2014;106(6):dju124.

11) Tecchio C, Scapini P, Pizzolo G, Cassatella MA. On the cytokines produced by human neutrophils in tumors. Semin Cancer Biol 2013; 23(3):159-70

12) Azab B, Bhatt VR, Phookan J, Murukutla S, Kohn N, Terjanian T, et al. Usefulness of the neutrophil-to-lymphocyte ratio in predicting short- and long-term mortality in breast cancer patients. Ann Surg
Oncol 2012;19(1):217-24.

13) Halazun KJ, Hardy MA, Rana AA, Woodland DC 4th, Luyten EJ, Mahadev S, et al. Negative impact of neutrophil-lymphocyte ratio on outcome after liver transplantation for hepatocellular carcinoma. Ann Surg 2009;250(1):141-51.

14) Jung MR, Park YK, Jeong O, Seon JW, Ryu SY, Kim DY, et al. Elevated preoperative neutrophil to lymphocyte ratio predicts poor survival following resection in late stage gastric cancer. J Surg Oncol 2011;104(5):504-10.

15) Gomez D, Farid S, Malik HZ, Young AL, Toogood GJ, Lodge JP, et al. Preoperative neutrophil-to-lymphocyte ratio as a prognostic predictor after curative resection for hepatocellular carcinoma. World J Surg 2008;32(8):1757-62.

16) Walsh SR, Cook EJ, Goulder F, Justin TA, Keeling NJ. Neutrophillymphocyte ratio as a prognostic factor in colorectal cancer. J Surg Oncol 2005;91(3):181-4.

17) Ali AA, McMillan DC, Matalka II, McNicol AM, McArdle CS. Tumour T-lymphocyte subset infiltration and tumour recurrence following curative resection for colorectal cancer. Eur J Surg Oncol 2004;30(3):292-5.

18) Sun W, Zhang L, Luo M, Hu G, Mei Q, Liu D, et al. Pretreatment hematologic markers as prognostic factors in patients with nasopharyngeal carcinoma: Neutrophil-lymphocyte ratio and platelet-lymphocyte ratio. Head Neck 2016;38 Suppl 1:E1332-40.

19) Song Y, Liu H, Gao L, Liu X, Ma L, Lu M, et al. Preoperative neutrophilto-lymphocyte ratio as prognostic predictor for hypopharyngeal squamous cell carcinoma after radical resections. J Craniofac Surg 2015;26(2):e137-40.

20) Sarraf KM, Belcher E, Raevsky E, Nicholson AG, Goldstraw $P$, Lim E. Neutrophil/lymphocyte ratio and its association with survival after complete resection in non-small cell lung cancer. J Thorac Cardiovasc Surg 2009;137(2):425-8. 